\title{
Using social network analysis to identify key stakeholders in agricultural biodiversity governance and related land-use decisions at regional and local level
}

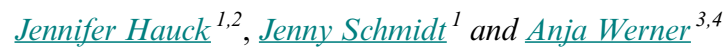

\begin{abstract}
In 2013 the European Commission launched its new green infrastructure strategy to make another attempt to stop and possibly reverse the loss of biodiversity until 2020 , by connecting habitats in the wider landscape. This means that conservation would go beyond current practices to include landscapes that are dominated by conventional agriculture, where biodiversity conservation plays a minor role at best. The green infrastructure strategy aims at bottom-up rather than top-down implementation, and suggests including local and regional stakeholders. Therefore, it is important to know which stakeholders influence land-use decisions concerning green infrastructure at the local and regional level. The research presented in this paper served to select stakeholders in preparation for a participatory scenario development process to analyze consequences of different implementation options of the European green infrastructure strategy. We used a mix of qualitative and quantitative social network analysis (SNA) methods to combine actors' attributes, especially concerning their perceived influence, with structural and relational measures. Further, our analysis provides information on institutional backgrounds and governance settings for green infrastructure and agricultural policy. The investigation started with key informant interviews at the regional level in administrative units responsible for relevant policies and procedures such as regional planners, representatives of federal ministries, and continued at the local level with farmers and other members of the community. The analysis revealed the importance of information flows and regulations but also of social pressure, considerably influencing biodiversity governance with respect to green infrastructure and biodiversity.
\end{abstract}

Key Words: actor analysis; common agricultural policy; coproduction of knowledge; green infrastructure; Net-Map; stakeholder analysis

\section{INTRODUCTION}

In Europe, where agrarian landscapes are perceived to be cultural entities from which society expects multiple benefits, conflicts between intensive agricultural production and environmental conservation are well known (Young et al. 2005). When users of the same resource have divergent values and conflicting interests it becomes necessary to understand the different perspectives of the actors involved to enable successful governance (Cash et al. 2006, Reed et al. 2009, Primmer et al. 2014). Therefore, policy makers have started to promote participation and the involvement of stakeholders into decision making and policy implementation (Reed 2008, Prager and Nagel 2008). Participation has shown to benefit the legitimacy of recommendations more generally but also the social outcomes of management (Bryson 2004, Young et al. 2013). Recent examples are participatory approaches recommended for the green infrastructure (GI) strategy, launched by the European Commission (EC) in 2013 to foster biodiversity conservation among other goals (EC 2013a, Kettunen et al. 2014). The strategy suggests GI implementation concerning landscapes that are dominated by conventional agriculture, where biodiversity conservation currently plays a minor role at best and emphasizes the need to involve local stakeholders to avoid conflicts and ensure prompt application (EC 2013a). Further, it is suggested to integrate the strategy in existing policies; in the case of agricultural landscapes the EC points to the Common Agricultural Policy (CAP). This integration poses the challenge that while the GI strategy is meant to be implemented bottom up, the CAP implementation usually follows a top-down approach (Repohl et al. 2015)
For a bottom-up approach, however, identifying key actors and stakeholders has been found crucial (Welp et al. 2006, Prager and Nagel 2008, Reed et al. 2009, Kok and Veldkamp 2011, Young et al. 2013) and actor analysis, also often called stakeholder analysis (Reed et al. 2009, Prell et al. 2011), has proven to be useful in governance contexts (Hermans 2008, Reed et al. 2009, Young et al. 2013). Although single actors are certainly important, it is essential to look at the governance network with its institutionalized relations, which develop because of shared interests in solving a problem (Newig et al. 2010). Prell et al. (2008, 2009, 2011) demonstrate how knowledge gained from analyzing their social networks can be harnessed for selecting stakeholders. Similar to Reed et al. (2009), or Gamper et al. (2012), Prell et al. (2011) suggest using a combination of methods e.g. to combine results from classical social network analysis (SNA) with a qualitative analysis of stakeholder knowledge to improve understanding of the relations (see also Beilin et al. 2013, Lienert et al. 2013, Stein et al. 2014, Bellotti 2015, Borg et al. 2015, Hauck et al. 2015).

The research conducted for this paper served to identify and select stakeholders relevant in the context of agricultural biodiversity governance and related land-use decisions at regional and local level in preparation for a participatory scenario development process to analyze consequences of different implementation options of the green infrastructure strategy (EC 2013b). The aim of this paper is to present the results of the identification and analysis of (a) actors at regional and local levels, (b) actors from other affected policy sectors, and (c) the vertical and horizontal interplay between actors at different levels and from different policy sectors.

${ }^{1}$ Helmholtz-Centre for Environmental Research - UFZ, ${ }^{2}$ CoKnow Consulting - Coproducing Knowledge for Sustainability, ${ }^{3}$ Ökolöwe - Umweltbund Leipzig e.V., ${ }^{4}$ Grüne Liga Sachsen e.V. 


\section{METHODS}

\section{General description of data collection and analysis}

Based on the suggestion by Hauck et al. (2015) to use participatory network analysis to coproduce network knowledge together with stakeholders, the data collection was done using the Net-Map tool. Net-Map involves collecting network data and at the same time participants provide descriptions of network relationships. These "network narratives" provide insights into the intersubjective meanings that actors attribute to relationships (Fuhse and Mützel 2011). The different data sets allow for triangulation between network structures and narratives (Gamper et al. 2012). There are many descriptions of data collection processes using the Net-Map tool (e.g., Hauck 2010, Schiffer and Hauck 2010, Aberman et al. 2012, Bell et al. 2013, Campbell et al. 2014, Stein et al. 2014, Hauck et al. 2015), therefore, we only briefly describe it here.

Before the Net-Map interviews, the research question is developed. In the beginning of the interview it is explained, e.g., "Who influences XY policy development?" Then the interviewee (s) are asked to name the actors they see as influencing the issue and write them down on actor cards, e.g., Post-its ${ }^{\circledR}$. The cards are then fixed to a large sheet of paper. In the second step of the interviews, links between actors, e.g. information flow, are recorded by drawing arrows between the actor cards. During the whole interview process, it is of utmost importance to record the narratives that are provided by the interviewees, e.g., why the networks are important or concrete examples for links between actors. To capture the perceived influence of the described actors, in the end, interviewees are asked to assess the influence of each actor on the Net-Map with reference to the issue at hand, and influence towers, made of flat round discs, are stacked proportionately beside the actor cards. This relational influence rating allows for a later comparison between the single interviews.

Some of the steps in the Net-Map interview, such as the eliciting of actors and the assessment of their relationships are similar to other SNA techniques (see, for example, Scott 2000, Prell 2012). Other steps, like the building of influence towers and the visualization, are complementary (for a detailed analysis of the benefits and limitations of Net-Map please see Hauck et al. 2015).

The analysis of the diverse data requires mixed methods. We used an approach suggested by Herz et al. (2015), who propose a combination of structural and content analysis, by posing questions to the network visualizations and narratives. The questions serve to structure and guide the analysis and are not meant to complement the research questions: "Which actors connect actors that would have otherwise been unconnected?"; "Which influence do the actors hold?"; "Which other characteristics do the actors have?"; "What kinds of relations do prevail?" We combined the approach from Herz et al. (2015) with an approach proposed by Prell et al. (2009), who suggest using the measure of centrality of actors. More details of the analysis are introduced in the case study context below.

\section{The mixed methods approach in the case study context}

The research presented in this paper served to select stakeholders in preparation for a spatially explicit scenario development process to explore policy implementation options. For the case study we selected a federal state in Germany, and four spatially explicit research sites in agricultural landscapes, each 400 ha large, with different amounts of existing GI structures and where complementary ecological research took place. The geography of the research sites roughly defined the network boundaries (cf. Newig et al. 2010).

\section{Data collection at the regional level}

We ran three pretest interviews with researchers working with stakeholders in the region using the question: "Who influences biodiversity in the agricultural landscapes in this federal state?" Based on scientific literature, we selected two links beforehand: information flows and regulatory flows. We did not define the links in further detail because we aimed at extracting their meaning from the qualitative data, i.e., the examples for links between actors that are given by the interviewees. A third link, the flows of social pressure, was suggested by one of the pretesters and was included in the interview design. After the links were established we asked the interview partners to rank the influence of the actors and closed the interview by asking whether he/she had any thoughts that he/she wanted to share with us.

We identified our first interviewees with the help of researchers who had worked on biodiversity issues in the area and then followed a snowball-sampling approach. Apart from direct recommendations, we also used the Net-Maps to identify interview partners, i.e., including persons from actor groups that were mentioned repeatedly. In total we conducted 11 interviews at the regional level and 8 interviews at the local level, which took between 1-2 hours. (More information on the interview partners can be found in Appendix 1.)

\section{Data collection at the local level}

Preliminary results at the regional level indicated that the biggest influence on biodiversity was perceived to be exerted by farmers via land-use and management decisions. Therefore, at the local level we asked directly, who is influencing farmers' land-use and management decisions. Another reason for the change of questions was based on unpublished interviews, which revealed that (a) farmers do not necessarily know the term biodiversity or interpret the wording as related to organic farming or (b) they perceive the term as rather negative. We tested the modified question and the three links from the regional level, which worked well and therefore included the pretest interview in our analysis. We also kept the third step of the interview and asked for the influence of the actors concerning farmers' land-use and management decisions. During the interview, we did ask probing questions that were aimed at farmers' land-use decisions relevant for biodiversity and green infrastructure but formulated these rather neutral, so as not to steer the conversation into the one or the other direction (pro or contra biodiversity protection).

\section{Data analysis}

We transcribed the interviews and listed all actors mentioned on both levels. We then calculated the normalized, average influence, from the number of discs each mentioned actor received during the interview (for more details see Hauck 2010, Schiffer and Hauck 2010), for each level separately and counted how often the respective actors were mentioned. The next step was to digitize the network data. The drawn Net-Maps were translated into a data matrix, i.e., all actors were horizontally and vertically entered into a data sheet and linked with absence/presence for the respective link. In order to have a value with which to compare the average influence, we calculated the degree and betweenness centrality of each actor from all networks but again separated by 
Table 1. The table presents the results of the interviews at the regional level concerning the average influence of the actors, the number of times the actors were mentioned, standardized betweenness centrality, and standardized degree centrality.

\begin{tabular}{|c|c|c|c|c|c|}
\hline Actor & Actor abbreviation & Influence & Times mentioned & $\begin{array}{l}\text { Betweenness } \\
\text { standardized }\end{array}$ & $\begin{array}{c}\text { Degree } \\
\text { standardized }\end{array}$ \\
\hline Banks & Banks & 0 & 1 & 0 & 0.2 \\
\hline Biogas producers & Biogas & 0.33 & 4 & 0 & 0.2 \\
\hline Broker & Broker & 0.06 & 1 & 0 & 0.8 \\
\hline Communities & Communities & 0.25 & 7 & 0 & 1.5 \\
\hline $\begin{array}{l}\text { Conservation area } \\
\text { administration }\end{array}$ & ConArea & 0.07 & 3 & 0 & 0.8 \\
\hline Consultants & Consultant & 0.13 & 4 & 0 & 1.4 \\
\hline Consumer & Consumer & 0.07 & 3 & 0 & 0.5 \\
\hline Land cooperation & Coop & 0.04 & 2 & 0 & 0.9 \\
\hline County & County & 0.08 & 3 & 0 & 1.3 \\
\hline Environmental NGOs & EnvNGO & 0.2 & 10 & 0 & 1.5 \\
\hline Farmers' associations & FA & 0.26 & 9 & 0.1 & 1.9 \\
\hline $\begin{array}{l}\text { Federal state agency for } \\
\text { agriculture and forests }\end{array}$ & FAAF & 0.45 & 11 & 0 & 1.6 \\
\hline Farmer & Farmer & 0.96 & 11 & 0.1 & 1.9 \\
\hline $\begin{array}{l}\text { Federal state ministry of } \\
\text { agriculture and environment }\end{array}$ & FMAE & 0.55 & 8 & 0 & 1.7 \\
\hline $\begin{array}{l}\text { Federal ministry of state } \\
\text { development and infrastructure }\end{array}$ & FMDI & 0.1 & 3 & 0 & 0.8 \\
\hline $\begin{array}{l}\text { Federal state nature } \\
\text { conservation authority }\end{array}$ & FNCA & 0.23 & 9 & 0 & 1.5 \\
\hline $\begin{array}{l}\text { Federal state department of } \\
\text { environmental conservation }\end{array}$ & FSDEC & 0.21 & 7 & 0 & 1.5 \\
\hline $\begin{array}{l}\text { Federal state office for } \\
\text { agriculture, forestry, and } \\
\text { horticulture }\end{array}$ & FSOAFH & 0.19 & 7 & 0 & 1.5 \\
\hline Hunters & Hunter & 0.12 & 5 & 0 & 1.4 \\
\hline Technical journal & Journal & 0.08 & 3 & 0 & 1 \\
\hline $\begin{array}{l}\text { Landscape management } \\
\text { associations }\end{array}$ & LMA & 0.32 & 8 & 0 & 1.5 \\
\hline General media & Media & 0.05 & 3 & 0 & 1 \\
\hline Land owner & Owner & 0.14 & 7 & 0 & 1.4 \\
\hline Public & Public & 0.06 & 5 & 0 & 1.1 \\
\hline $\begin{array}{l}\text { Regional nature conservation } \\
\text { authority }\end{array}$ & RNCA & 0.27 & 9 & 0 & 1.5 \\
\hline Science & Science & 0.12 & 6 & 0 & 1 \\
\hline $\begin{array}{l}\text { Special purpose association (e. } \\
\text { g., Water and Soil } \\
\text { Associations) }\end{array}$ & SPA & 0.11 & 3 & 0 & 1.3 \\
\hline Wholesaler & Trade & 0.14 & 4 & 0 & 0 \\
\hline
\end{tabular}

regional and local level using the SNA software Visone (Brandes and Wagner 2004). Degree centrality is the count of an actor's ingoing and outgoing links. Betweenness centrality is the measure of how often an actor is found on the shortest path between two other actors that are otherwise disconnected (Wasserman and Faust 1994, Calvet-Mir et al. 2015). In our analysis we focused on the following points: (a) actors who were mentioned particularly often, had a high influence, and a high centrality; (b) actors, for whom these values diverged; and (c) actors with weak values. This first quantitative analysis served as starting point to analyze the qualitative data (transcripts), by raising additional questions, guided by those formulated by Herz et al. (2015) mentioned above.

After the aggregated calculation we plotted the networks separated for the local and regional level (see Appendices 2 and 3) but also for the different networks (information, regulation, and social pressure). We looked for links that were mentioned particularly often because these were perceived by a number of interview partners. We then screened through the transcript material to analyze which information were given for these links and whether we could find a consensus or divergence about the respective social relations.

\section{RESULTS and DISCUSSION}

We conducted 11 interviews at the regional and 8 at the local level, which took between 1-2 hours. (More information on the interview partners can be found in Appendix 1.)

\section{Actors and their influence}

In total, for both the local and the regional level, 72 different actors were mentioned, with 41 in local and 61 in regional interviews. Tables 1 and 2 show the actors with their average influence, who were mentioned two times or more and the betweenness and degree centrality. 
Table 2. The table presents the results of the interviews at the local level concerning, the average influence of the actors, the number of times the actors were mentioned, standardized betweenness centrality, and standardized degree centrality.

\begin{tabular}{|c|c|c|c|c|c|}
\hline Actor & Actor abbreviation & Influence & Times mentioned & $\begin{array}{l}\text { Betweenness } \\
\text { standardized }\end{array}$ & $\begin{array}{c}\text { Degree } \\
\text { standardized }\end{array}$ \\
\hline Banks & Banks & 0.06 & 2 & 0 & 0.15 \\
\hline Biogas producers & Biogas & 0.1 & 2 & 0 & 0.15 \\
\hline Broker & Broker & 0.23 & 2 & 0 & 0.19 \\
\hline Communities & Communities & 0.15 & 5 & 0.1 & 1 \\
\hline $\begin{array}{l}\text { Conservation area } \\
\text { administration }\end{array}$ & ConArea & 0 & 0 & 0 & 0 \\
\hline Consultants & Consultant & 0.09 & 4 & 0 & 0.7 \\
\hline Consumer & Consumer & 0.05 & 1 & 0 & 0.1 \\
\hline Land cooperation & Coop & 0.18 & 3 & 0 & 0.9 \\
\hline County & County & 0.03 & 1 & 0 & 0.2 \\
\hline Environmental NGOs & EnvNGO & 0 & 0 & 0 & 0 \\
\hline Farmers' associations & FA & 0 & 3 & 0.1 & 0.9 \\
\hline $\begin{array}{l}\text { Federal state agency for } \\
\text { agriculture and forests }\end{array}$ & FAAF & 0.5 & 8 & 0.1 & 1.12 \\
\hline Farmer & Farmer & 0.83 & 8 & 0.3 & 1.6 \\
\hline $\begin{array}{l}\text { Federal state ministry of } \\
\text { agriculture and environment }\end{array}$ & FMAE & 0.15 & 3 & 0 & 0.4 \\
\hline $\begin{array}{l}\text { Federal ministry of state } \\
\text { development and } \\
\text { infrastructure }\end{array}$ & FMDI & 0 & 0 & 0 & 0 \\
\hline $\begin{array}{l}\text { Federal state nature } \\
\text { conservation authority }\end{array}$ & FNCA & 0.14 & 3 & 0 & 0.7 \\
\hline $\begin{array}{l}\text { Federal state department of } \\
\text { environmental conservation }\end{array}$ & FSDEC & 0.07 & 1 & 0 & 0.4 \\
\hline $\begin{array}{l}\text { Federal state office for } \\
\text { agriculture, forestry, and } \\
\text { horticulture }\end{array}$ & FSOAFH & 0.1 & 2 & 0 & 0.4 \\
\hline Hunters & Hunter & 0.13 & 4 & 0 & 0.9 \\
\hline Technical journal & Journal & 0.32 & 5 & 0 & 0.6 \\
\hline $\begin{array}{l}\text { Landscape management } \\
\text { associations }\end{array}$ & LMA & 0 & 0 & 0 & 0.7 \\
\hline General media & Media & 0.26 & 2 & 0 & 0.10 \\
\hline Land owner & Owner & 0.43 & 9 & 0 & 0.8 \\
\hline Public & Public & 0.01 & 1 & 0 & 0.3 \\
\hline $\begin{array}{l}\text { Regional nature conservation } \\
\text { authority }\end{array}$ & RNCA & 0.06 & 3 & 0 & 0.6 \\
\hline Science & Science & 0 & 1 & 0 & 0.3 \\
\hline $\begin{array}{l}\text { Special purpose association (e. } \\
\text { g., Water and Soil } \\
\text { Associations) }\end{array}$ & SPA & 0 & 1 & 0 & 0.3 \\
\hline Wholesaler & Trade & 0.2 & 4 & 0 & 0.4 \\
\hline
\end{tabular}

"Which influence do the actors hold?," "Which other characteristics do the actors have?," and "Which actors connect actors that would have otherwise been unconnected?"

Some similarities appear between the local and the regional level: Farmers were mentioned in all interviews, were rated the most important actors, and have both the highest betweenness and degree centrality. The federal state agency for agriculture and forests (FAAF) was likewise mentioned in all interviews, and was rated the second most important actor, albeit receiving only half of the influence rating compared to farmers. Its betweenness and degree centrality was also high on both levels. The third most influential group of actors at the local level were the land owners, a group that consists of private land owners, churches, and the federal republic of Germany. They were mentioned in seven of the eight local interviews. Although they were also mentioned 7 times out of 11 at the regional level, their perceived influence was rated rather low there. More than half of the interviewees at the local level stated technical journals to be important, which however did not receive much attention at the regional level. Rather often (about half of the interviews) trade (agricultural wholesaler) was mentioned, but its influence was rated relatively low. Although not perceived to be very important, communities received high betweenness and degree centrality values at the local level. They did not play any role at the regional level.

The analysis of the actors at the regional level revealed a large number of influential actors from administrative institutions. Particularly important in terms of biodiversity at the regional level appears to be the federal state ministry for agriculture and environment (FMAE). Although it was mentioned by only three interview partners at the local level and given little influence, it was deemed important by eight interviewees at the regional level with the second highest influence score and high betweenness and 
degree centrality values (even higher than the FAAF). Almost as important at the regional level are the federal state nature conservation authority (FNCA) and the regional nature conservation authority (RNCA).

Widely differing perceptions in terms of influence and centralities can be found when looking at farmers' associations (FA) and to some extent the landscape management associations (LMA). They were mentioned by most regional interview partners and were also given greater influence. Both actors belong to a group called representatives of public interests (German: Träger öfentlicher Belange) and their influence is derived from the possibility to submit their statements, e.g., when a regional plan is updated or when regional implementation of the CAP is designed. The FA was mentioned by three local interview partners only and was perceived as not being influential at all while the LMA was not even named.

\section{Links drawn between actors}

"What kinds of relations do prevail?"

Similar to the actor characteristics, the networks were analyzed separately for the local and the regional level. All interview partners at both levels drew the information and regulation networks. At both levels some interview partners were uncomfortable drawing links for social pressure, so only four networks for each level were drawn. At the local level, only the social pressure between owners and farmers and social pressure within the group of farmers were mentioned in more than one interview. At the regional level some links of social pressure were drawn in three or four interviews, namely the ones between FA and farmers, between farmers and community, environmental NGOs and FA, environmental NGOs and FMAE (each three times), the public and farmers, owners and farmers, and environmental NGOs and farmers (each four times). Network visualizations for all links together can be found in Appendix 2 and 3 .

Information flow and regulations were mentioned most as links between actors. An analysis of the qualitative data revealed that although regulations are mainly institutionalized relations like the payment of money or duties that need to be fulfilled to receive that money, some land owners hold certain values and concepts attached to land use and therefore force or push farmers toward certain practices. Information flows include mandatory exchanges, for example, between farmers and FAAF, but also cover farmers talking to other farmers about practices.

As stated in the methods section, we used the quantitative parts of the analysis to raise questions for the analysis of the qualitative material. Some of the differences in the answers between the local and regional level can of course be attributed to the alteration of the question for the local interviews. However, most of the regional interview partners also explained that the main actors influencing biodiversity are farmers because they make the final land-use and management decisions, and much can be understood when looking at who is influencing these decisions. Therefore, we attributed difference of perceived influence not simply to the different questions but tried to find explanations in the network flows and qualitative data. Based on the description of the actors' influence and the quantitative analysis of the network data, we formulated questions guiding our qualitative data analysis.

\section{Networks of information flows, regulation, and social pressure}

"Why do farmers and the federal state agency for agriculture and forests (FAAF) have such high perceived influence as well as high centrality?"

The high importance of farmers can be attributed to the fact that farmers make the final land-use and management decisions that in any way affect biodiversity. Their high centrality shows that farmers are connected to many other actors. When looking at the qualitative information concerning these connections it becomes apparent that many different actors influence or try to influence farmers' decisions on biodiversity directly but also indirectly through general land-use or management decisions. Most respondents stated that the decisions are mostly influenced by the direct payments of the CAP. The payments are related to certain conditions that have to be fulfilled and farmers receive information on these from the FAAF, explaining its strong appearance in the local information network. More importantly the FAAF is responsible for paying out the money of the CAP, controlling cross-compliance adherence, and executing environmental programs. Although certainly less important concerning influence and centrality, there is a second administrative actor in the regulatory context that is influencing farmers' decisions: the RNCA, which is responsible for controlling implementation of environmental measures and reporting violations, e.g., in the context of cross-compliance or agri-environmental measures, which can lead to a reduction of CAP-payments.

Although local interviewees depicted only the FAAF as an important source of information among administrative agencies, regional interview partners linked other agencies, such as the federal state office for agriculture, forestry, and horticulture (FSOAFH), RNCA, or FNCA with farmers. However, even though information was exchanged with (some) farmers, certain important information about opportunities concerning agrienvironmental schemes had not reached the farmers we interviewed. This might be an explanation why these actors do not appear to be important at the local level. Another explanation might be that other bodies than the FAAF are not perceived as actors because they communicate with farmers through the FAAF.

Within the group of farmers social pressure takes place. As an example, interview partners reported that farmers usually closely observe the practices of each other and "tease" each other, for example when one is late with a particular task or when fields are getting "untidy." This fits quite well with an observation made by Wood et al. (2014), that farmers' information sources are mainly other farmers, and before they try something new they want to know if fellow farmers are partaking and what their experiences are. Sutherland et al. (2012) also found that social relations among farmers plays a crucial role in adopting new farming methods and it has also been shown for the uptake of agri-environmental measures (see Lastra-Bravo et al. 2015 for examples). Two farmers explicitly emphasized that emotional conceptions and their own awareness of environmental contexts plays a major role in their land-use decisions. Contrary to findings from other authors (e.g., Lastra-Bravo et al. 2015) one farmer found his connection with the land important and perceived differences between farmers who were born in the area and those who had moved there later 
in their lives. This last point was supported by the interviewed agricultural consultant who stated that farmers planning to hand the farm over to an heir, would farm their land more sustainably.

\begin{abstract}
"Where does the difference in influence perception and centralities between the local and regional level concerning the federal state ministry of agriculture and environment (FMAE) but also other administrative agencies come from?"
\end{abstract}

The FMAE is responsible for the final decision making concerning the detailed design of the measures in the context of the CAP but also for other programs, e.g., with regard to biodiversity conservation. It also, through its subordinate agencies like the FSOAFH, influences biodiversity-relevant aspects of farming like giving advice for which and how much pesticides to use. High centrality values at the regional level can be explained in this context, namely that the FMAE receives additional information and recommendations for program design from many different actors and also provides information about the programs to them. Most local interview partners were unfamiliar with these structures and hence did not consider them. Further, although the FMAE makes the decisions, the implementation (via information and regulations) and thus the experienced impact on farmers is ascribed to the FAAF, which is therefore most important for farmers.

A number of interview partners from the local level also mentioned that information from farmers concerning requirements, for example, on practicality of measures was submitted to the FMAE via the FAAF. However, farmers felt that their concerns were not taken into consideration by the FMAE. Although there could be valid reasons, e.g., that farmers' requirements would be counterproductive for biodiversity protection, decisions seem not always to be transparent or inclusive, which may be counterproductive for the adoption of measures (Prager and Nagel 2008, Ingold 2014).

\section{"What makes land owners and technical journals influential actors for decision making at the local level?"}

Similar to findings by Steen-Adams et al. (2015), our qualitative data revealed that when farmers pay rent to the land owners, they are bound to use the land in exactly the way defined in lease agreements. Changes in land use that would lead to a reclassification of the land, e.g., planting a hedge or converting arable into grass land, are not possible. Although what can and cannot be done with the land is fixed, crop management, e.g., how often pesticides are used or how much fertilizer is applied, is usually not part of lease agreements. However, farmers and other interviewees reported that land owners prefer to have their land kept in a "tidy" state, implying for example strict weed control. Because of high competition for land based on increasing bioenergy production and financial investments, owners have a strong position because farmers are interested in renewing their lease agreements, which usually only run for 10 years. Therefore, farmers try to maintain good relations with land owners, who in turn can use this to influence farmers' decisions.

A source of information often ignored at the regional level, relevant particularly among the interviewed farmers, were technical journals such as top agrar or Bauernzeitung. These provide information about prices of crops and supplies or weather forecasts and product reviews, important when it comes to decision making about harvesting or sowing dates or the application for certain fertilizers or pesticides but also which agrienvironmental measures are worthwhile or how to efficiently fulfill CAP requirements.

"Why do interview partners at the local level, and here farmers in
particular, not attribute any influence to farmers' associations
(FA), despite comparably high centralities and importance
attributed at the regional level?" An interesting link at the regional level is the link between farmers and farmers' associations. Farmers pay a membership fee and expect the FA to represent their interests. This kind of relationship seems, however, not to influence farmers' decisions and one farmer reported that he sees the association more as an ambassador of the farmers toward society. Another interviewee explained that particularly at the EU level, he does not feel well represented because he has the feeling that the umbrella organization of FAs is trying to influence decision making in favor of large scale farming and traders.

"Which roles do communities play in land-use decision making?" In the area, the community basically equals the inhabitants of the villages within which the farmers and other land users, like members of the LMA, live. These inhabitants use the landscape for recreational uses, some are land owners that lend their property out to farmers, and many are interested in a well-maintained grey infrastructure and a tidy and orderly appearance of the landscape particularly close to their homes. Farmers have certain ordinances, such as not to work late at night to avoid noise disturbance. Further, for example, they can be held responsible when they damage dirt roads with their heavy vehicles or when they plough to close to field margins or water bodies. However, sometimes violations become necessary, e.g., when in summertime, harvesting is determined by good weather and working late hours cannot be avoided. Usually, communities overlook these violations because they also depend on farmers, who often help with winter services or the maintenance of hedges. So even if there are concerns or even complaints voiced by members of the community, farmers are frequently sparred.

"Why are LMA considered influential at the regional but not at the local level?"

The differences in the perceived influence between local and regional level concerning the LMAs can probably be attributed to the different questions, as well as to the fact that the farmers we interviewed were not involved and hence their decisions were not influenced by the LMA. However, the FA, interviewed for the regional level, told us that the LMA does inform farmers about breeding birds so they can spare the respective parts of the fields. The LMA also implements a number of other measures toward biodiversity conservation themselves.

\section{CONCLUSION}

The research conducted for this paper served to select stakeholders in preparation for a scenario development process to analyze consequences of implementation options of the European green infrastructure strategy (EC 2013b) with a focus on agricultural landscapes. We chose a mixed methods approach combining the analysis of quantitative and qualitative social network data, to not only identify key stakeholders but to also reveal their relationships concerning information, regulation, and social pressure. 
Unsurprisingly, actors related to the implementation of the CAP at the regional and local level turned out to be important. Because farmers are the ultimate land-use decision makers, e.g., in choosing from a variety of types of ecological focus areas within the greening measure of the CAP (for example, between cash crops and field elements like hedge rows or flower strips), they were identified to have considerable influence on how effective these measures will work to benefit biodiversity in rural areas.

Based on our analysis we invited the identified stakeholder groups to the initial scenario development workshop. For the groups that were rather broadly defined, such as "community," we tried to identify representatives such as the mayor. Also we identified the farmers who farmed within our research sites. Although we made efforts to include different stakeholders in our workshop, particularly local actors did not join. Because our analysis, similar to Ingold (2014), revealed the importance of the local level stakeholders, we decided to organize additional local field visits and invited farmers, community representatives, landscape management agencies, as well as local branches of the farmer associations.

The mixed methods approach was time intensive, not only because the interviews were rather long at sometimes two hours and more, but also because they yielded a wealth of data that had to be processed and analyzed. Nevertheless, we conclude that we were not only able to identify key stakeholders, but also to get a rich understanding of the different perspectives influencing or being affected by biodiversity governance. This knowledge helped us further to engage stakeholders in their preferred ways, assisted us in finding the right language to address the different stakeholder groups, and facilitated the co-production of knowledge relevant to stakeholders particularly in connecting them with each other in the research process.

Responses to this article can be read online at: http://www.ecologyandsociety.org/issues/responses. $\mathrm{php} / 8596$

\section{Acknowledgments:}

This research was funded by the ERA-Net BiodivERsA, with the national funder BMBF, part of the 2011-2012 BiodivERs A call for research proposals.

\section{LITERATURE CITED}

Aberman, N.-L., M. Johnson, K. Droppelmann, E. Schiffer, R. Birner, and P. Gaff. 2012. Mapping the contemporary fertilizer policy landscape in Malawi. A guide for policy researchers. IFPRI Discussion Paper 01204. International Food Policy Research Institute, Washington, D.C., USA.

Beilin, R., N. T. Reichelt, B. J. King, A. Long, and S. Cam. 2013. Transition landscapes and social networks: examining on-gound community resilience and its implications for policy settings in multiscalar systems. Ecology and Society 18(2):30. http://dx.doi. org/10.5751/es-05360-180230

Bell, A. R., N.-L. Aberman, F. Zaidi, and B. Wielgosz. 2013. Progress of constitutional change and irrigation management transfer in Pakistan: insights from a net-map exercise. Water International 38:515-535. http://dx.doi.org/10.1080/02508060.2013.827893

Bellotti, E. 2015. Qualitative networks: mixed methods in sociological research. Routledge, London, UK.

Borg, R., A. Toikka, and E. Primmer. 2015. Social capital and governance: a social network analysis of forest biodiversity collaboration in Central Finland. Forest Policy and Economics 50:90-97. http://dx.doi.org/10.1016/j.forpol.2014.06.008

Brandes, U., and D. Wagner. 2004. Analysis and visualization of social networks. Pages 321-340 in M. Jünger and P. Mutzel, editors. Graph drawing software. Springer, Berlin, Germany. http:// dx.doi.org/10.1007/978-3-642-18638-7 15

Bryson, J. M. 2004. What to do when stakeholders matter. Stakeholder identification and analysis techniques. Public Management Review 6(1):21-53. http://dx.doi.org/10.1080/14719030410001675722

Calvet-Mir, L., S. Maestre-Andrés, J. L. Molina, and J. van den Bergh. 2015. Participation in protected areas: a social network case study in Catalonia, Spain. Ecology and Society 20(4):45. http://dx.doi.org/10.5751/es-07989-200445

Campbell, N., E. Schiffer, A. Buxbaum, E. McLean, C. Perry, and T. M. Sullivan. 2014. Taking knowledge for health the extra mile: participatory evaluation of a mobile phone intervention for community health workers in Malawi. Global Health: Science and Practice 2(1):23-34. http://dx.doi.org/10.9745/ghsp-d-13-00141

Cash, D. W., W. Adger, F. Berkes, P. Garden, L. Lebel, P. Olsson, L. Pritchard, and O. Young. 2006. Scale and cross-scale dynamics: governance and information in a multilevel world. Ecology and Society 11(2):8. [online] URL: http://www.ecologyandsociety. org/vol11/iss $2 /$ art $8 /$

European Commission (EC). 2013a. Technical information on green infrastructure (GI). Commission staff working document. Accompanying the document. Communication from the Commission to the European Parliament, the Council, the European Economic and Social Committee and the Committee of the Regions. Green Infrastructure (GI) - Enhancing Europe's Natural Capital. COM(2013) 249 final. EC, Brussels, Belgium. [online] URL: http://eur-lex.europa.eu/legal-content/EN/TXT/ PDF/?uri=CELEX:52013SC0155\&from=EN

European Commission (EC). 2013b. Green infrastructure (GI) enhancing Europe's natural capital. Communication from the Commission to the European Parliament, the Council, the European Economic and Social Committee and the Committee of the Regions. COM(2013) 249 final. EC, Brussels, Belgium. [online] URL: http://eur-lex.europa.eu/resource.html?uri=cellar: d41348f2-01d5-4abe-b817-4c73e6f1b2df.0014.03/DOC 1\&format= PDF

Fuhse, J., and S. Mützel. 2011. Tackling connections, structure, and meaning in networks: quantitative and qualitative methods in sociological network research. Quality \& Quantity 45:1067-1089. http://dx.doi.org/10.1007/s11135-011-9492-3

Gamper, M., M. Schönhuth, and M. Kronenwett. 2012. Bringing qualitative and quantitative data together: collecting network data with the help of the software tool VennMaker. Pages 193-214 in M. Safar, and K. A. Mahdi, editors. Social networking and 
community behavior modeling: qualitative and quantitative measures. IGI Global, Hershey, Pennsylvania, USA. http://dx. doi.org/10.4018/978-1-61350-444-4.ch011

Hauck, J. 2010. Managing social-ecological systems for resilience: fisheries in the small reservoirs of northern Ghana. ZEF-Ecology and Development Series No. 75. Bonn, Germany.

Hauck, J., C. Stein, E. Schiffer, and M. Vandewalle. 2015. Seeing the forest and the trees: facilitating participatory network planning in environmental governance. Global Environmental Change 35:400-410. http://dx.doi.org/10.1016/j.gloenvcha.2015.09.022

Hermans, L. M. 2008. Exploring the promise of actor analysis for environmental policy analysis: lessons from four cases in water resources management. Ecology and Society 13(1):21. [online] URL: http://www.ecologyandsociety.org/vol13/iss1/art21/

Herz, A., L. Peters, and I. Truschkat. 2015. How to do qualitative strukturale Analyse? Die qualitative Interpretation von Netzwerkkarten und erzählgenerierenden Interviews. Forum: Qualitative Social Research 16(1):9. [online] URL: http://www. qualitative-research.net/index.php/fqs/article/view/2092/3746

Ingold, K. 2014. How involved are they really? A comparative network analysis of the institutional drivers of local actor inclusion. Land Use Policy 39:376-387. http://dx.doi.org/10.1016/ j.landusepol.2014.01.013

Kettunen, M., E. Apostolopoulou, D. Bormpoudakis, J. Cent, A. Letourneau, M. Koivulehto, R. Paloniemi, M. GrodzińskaJurczak, R. Mathevet, A. Scott, and S. Borgström. 2014. EU green infrastructure: opportunities and the need for addressing scales. In K. Henle, S. Potts, W. Kunin, Y. Matsinos, J. Simila, J. Pantis, V. Grobelnik, L. Penev, and J. Settele, editors. Scaling in ecology and biodiversity conservation. Advanced Books. Pensoft, Sofia, Bulgaria. http://dx.doi.org/10.3897/ab.e1169

Kok, K., and T. A. Veldkamp. 2011. Scale and governance: conceptual considerations and practical implications. Ecology and Society 16(2):23. [online] URL: http://www.ecologyandsociety. org/vol16/iss2/art23/

Lastra-Bravo, X. B., C. Hubbard, G. Garrod, and A. TolónBecerra. 2015. What drives farmers' participation in EU agrienvironmental schemes?: results from a qualitative meta-analysis. Environmental Science \& Policy 54:1-9. http://dx.doi.org/10.1016/ j.envsci.2015.06.002

Lienert, J., F. Schnetzer, and K. Ingold. 2013. Stakeholder analysis combined with social network analysis provides fine-grained insights into water infrastructure planning processes. Journal of Environmental Management 125:134-148. http://dx.doi.org/10.1016/ j.jenvman.2013.03.052

Newig, J., D. Günther, and C. Pahl-Wostl. 2010. Synapses in the network: learning in governance networks in the context of environmental management. Ecology and Society 15(4):24. [online] URL: http://www.ecologyandsociety.org/vol15/iss4/ $\underline{\operatorname{art} 24 /}$

Prager, K., and U. J. Nagel. 2008. Participatory decision making on agri-environmental programmes: a case study from SachsenAnhalt (Germany). Land Use Policy 25(1):106-115. http://dx.doi. org/10.1016/j.landusepol.2007.03.003
Prell, C. 2012. Social network analysis: history, theory and methodology. Sage, London, UK.

Prell, C., K. Hubacek, C. Quinn, and M. Reed. 2008. Who's in the social network? When stakeholders influence data analysis. Systemic Practice and Action Research 21(6):443-458. http://dx. doi.org/10.1007/s11213-008-9105-9

Prell, C., K. Hubacek, and M. Reed. 2009. Stakeholder analysis and social network analysis in natural resource management. Society and Natural Resources 22(6):501-518. http://dx.doi. org/10.1080/08941920802199202

Prell, C., M. Reed, and K. Hubacek. 2011. Social network analysis for stakeholder selection and the links to social learning and adaptive co-management. Pages 95-118 in Ö. Bodin, and C. Prell, editors. Social networks and natural resource management: uncovering the social fabric of environmental governance. Cambridge University Press, Cambridge, UK. http://dx.doi. org/10.1017/cbo9780511894985.006

Primmer, E., R. Paloniemi, R. Mathevet, E. Apostolopoulou, J. Tzanopoulos, I. Ring, M. Kettunen, J. Similä, J. Cent, M. Grodzińska-Jurczak, T. Koellner, P. Antunes, J. D. Pantis, S. G. Potts, and R. Santos. 2014. An approach to analysing scalesensitivity and scale-effectiveness of governance in biodiversity conservation. Pages 241-262 in F. Padt, P. Opdam, N. Polman, and C. Termeer, editors. Scale-sensitive governance of the environment. John Wiley \& Sons, Oxford, UK. http://dx.doi. org/10.1002/9781118567135.ch15

Reed, M. S. 2008. Stakeholder participation for environmental management: a literature review. Biological Conservation 141 (10):2417-2431. http://dx.doi.org/10.1016/j.biocon.2008.07.014

Reed, M. S., A. Graves, N. Dandy, H. Posthumus, K. Hubacek, J. Morris, C. Prell, C. H. Quinn, and L. C. Stringer. 2009. Who's in and why? A typology of stakeholder analysis methods for natural resource management. Journal of Environmental Management 90(5):1933-1949. http://dx.doi.org/10.1016/j. jenvman.2009.01.001

Repohl, M., J. Schmidt, J. Hauck, and S. Weiland. 2015. Analyse des Politikintegrationspotentials der EU-Strategie für Grüne Infrastruktur - untersucht am Beispiel der Gemeinsamen Agrarpolitik der EU. UFZ-Diskussionspapier 10/2015. HelmholtzZentrum für Umweltforschung - UFZ, Leipzig, Germany. [online] URL: http://www.ufz.de/index.php?de=14487

Schiffer, E., and J. Hauck. 2010. Net-Map: collecting social network data and facilitating network learning through participatory influence network mapping. Field Methods 22 (3):231-249. http://dx.doi.org/10.1177/1525822x10374798

Scott, J. 2000. Social network analysis: a handbook. Sage, London, UK.

Steen-Adams, M. M., N. Langston, M. D. O. Adams, and D. J. Mladenoff. 2015. Historical framework to explain long-term coupled human and natural system feedbacks: application to a multiple-ownership forest landscape in the northern Great Lakes region, USA. Ecology and Society 20(1):28. http://dx.doi. org/10.5751/es-06930-200128 
Stein, C., J. Barron, L. Nigussie, B. Gedif, T. Amsalu, and S. Langan. 2014. Advancing the water-energy-food nexus: social networks and institutional interplay in the Blue Nile. WLE Research for Development (R4D) Learning Series 2. International Water Management Institute, Colombo, Sri Lanka. [online] URL: https://www.sei-international.org/publications? pid=2573 http://dx.doi.org/10.5337/2014.223

Sutherland, L.-A., D. Gabriel, L. Hathaway-Jenkins, U. Pascual, U. Schmutz, D. Rigby, R. Godwin, S. M. Sait, R. Sakrabani, W. E. Kunin, T. G. Benton, and S. Stagl. 2012. The "neighbourhood effect": a multidisciplinary assessment of the case for farmer coordination in agri-environmental programmes. Land Use Policy 29(3):502-512. http://dx.doi.org/10.1016/j.landusepol.2011.09.003

Wasserman, S., and K. Faust. 1994. Social network analysis: methods and applications. Cambridge University Press, Cambridge, UK. http://dx.doi.org/10.1017/cbo9780511815478

Welp, M., A. de la Vega-Leinert, S. Stoll-Kleemann, and C. C. Jaeger. 2006. Science-based stakeholder dialogues: theories and tools. Global Environmental Change 16(2):170-181. http://dx.doi. org/10.1016/j.gloenvcha.2005.12.002

Wood, B. A., H. T. Blair, D. I. Gray, P. D. Kemp, P. R. Kenyon, S. T. Morris, and A. M. Sewell. 2014. Agricultural science in the wild: a social network analysis of farmer knowledge exchange. PLoS ONE 9(8):e105203. http://dx.doi.org/10.1371/journal. pone. 0105203

Young, J. C., A. Jordan, K. R. Searle, A. Butler, D. S. Chapman, P. Simmons, and A. D. Watt. 2013. Does stakeholder involvement really benefit biodiversity conservation? Biological Conservation 158:359-370. http://dx.doi.org/10.1016/j.biocon.2012.08.018

Young, J., A. Watt, P. Nowicki, D. Alard, J. Clitherow, K. Henle, R. Johnson, E. Laczko, D. McCracken, S. Matouch, J. Niemela, and C. Richards. 2005. Towards sustainable land use: identifying and managing the conflicts between human activities and biodiversity conservation in Europe. Biodiversity and Conservation 14(7):1641-1661. http://dx.doi.org/10.1007/s10531-004-0536- 


\section{Appendix 1.}

Table A1. Information about interview partners from the regional and local level

\begin{tabular}{llll}
\hline \hline No. & Level & Date & Institution \\
\hline 1 & regional & 26.03 .2013 & Federal state agency for agriculture and forests \\
2 & regional & 30.05 .2013 & Farmers' associations \\
3 & regional & 07.01 .2013 & Federal state department of environmental conservation_1 \\
4 & regional & 17.01 .2013 & Federal state department of environmental conservation_2 \\
5 & regional & 12.02 .2013 & Federal state office for agriculture, forestry and horticulture \\
6 & regional & 16.01 .2013 & Advisory board for nature conservation \\
7 & regional & 30.11 .2012 & Scientific organization \\
8 & regional & 25.07 .2013 & Regional nature conservation authority \\
9 & regional & 25.07 .2013 & Regional planning \\
10 & regional & 11.11 .2013 & Association of organic farmers \\
11 & regional & 26.07 .2013 & Technical journal \\
& & & \\
1 & local & 01.03 .2013 & Hunter \\
2 & local & 01.03 .2013 & Farmer_1 \\
3 & local & 19.03 .2013 & Farmer_2 \\
4 & local & 30.03 .2013 & Farmer_3 \\
5 & local & 12.07 .2013 & Farmer_4 \\
6 & local & 19.03 .2013 & Agricultural consultant \\
7 & local & 29.07 .2013 & Landscape management association \\
8 & local & 29.07 .2013 & Mayor \\
\hline & & &
\end{tabular}




\section{Appendix 2.}

Figure A2.1. Regional network when two and more links between actors were mentioned

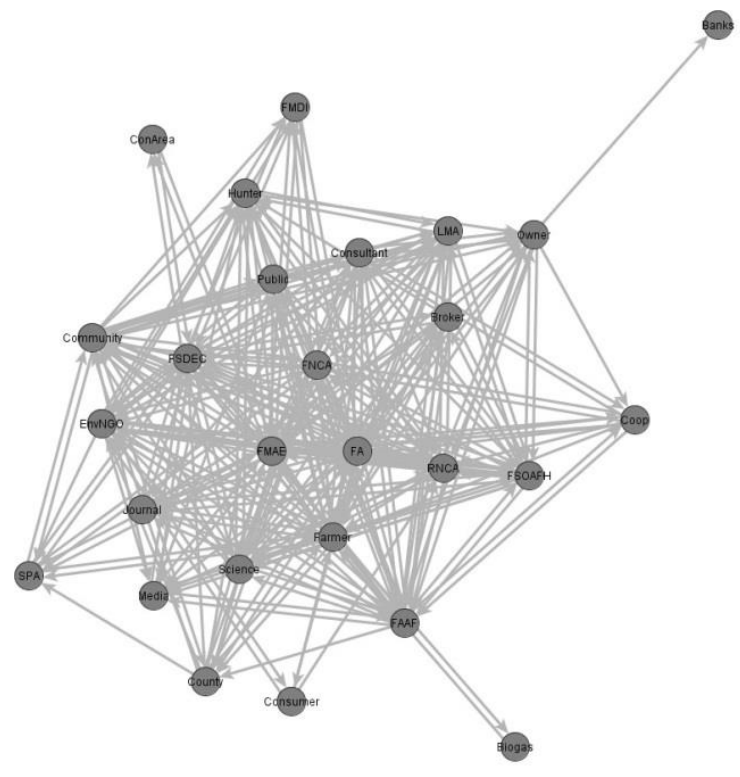


Figure A2.2. Regional network when three and more links between actors were mentioned

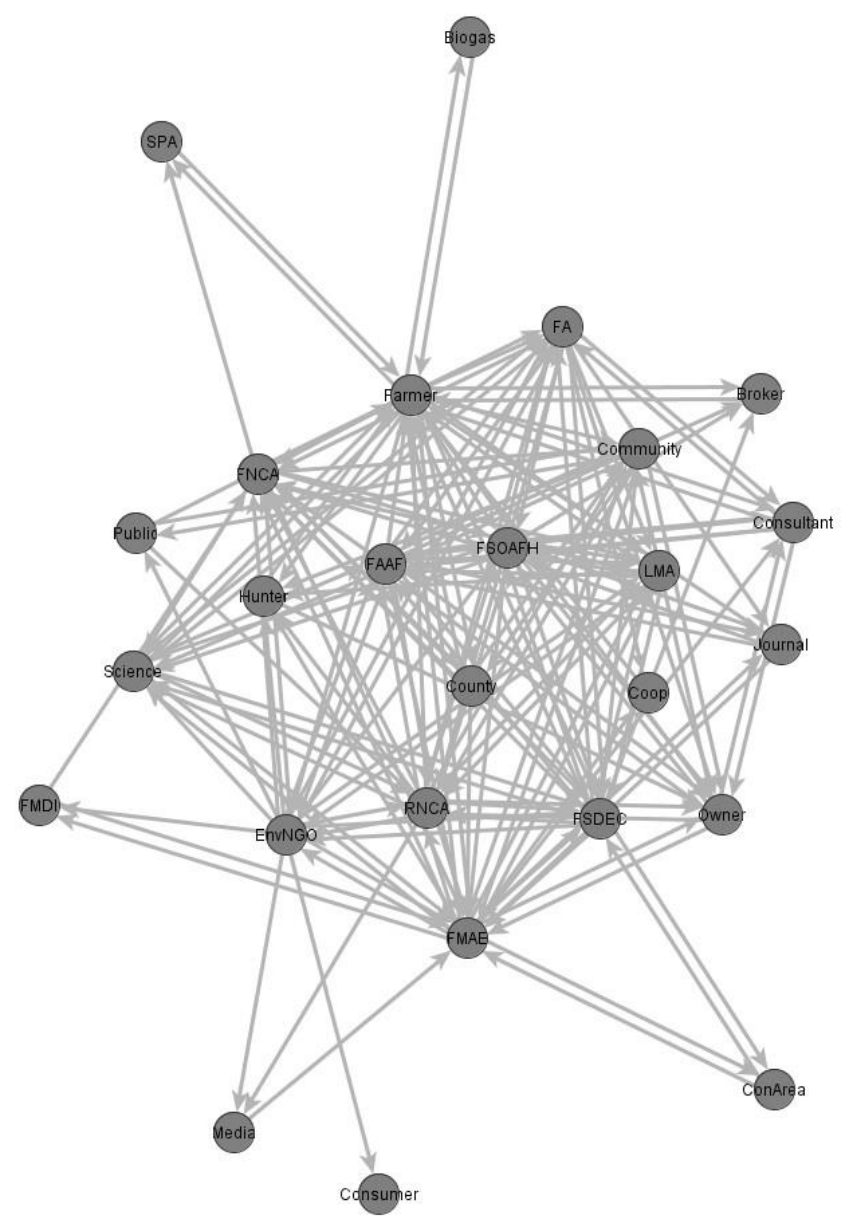

Figure A2.3. Regional network when four and more links between actors were mentioned

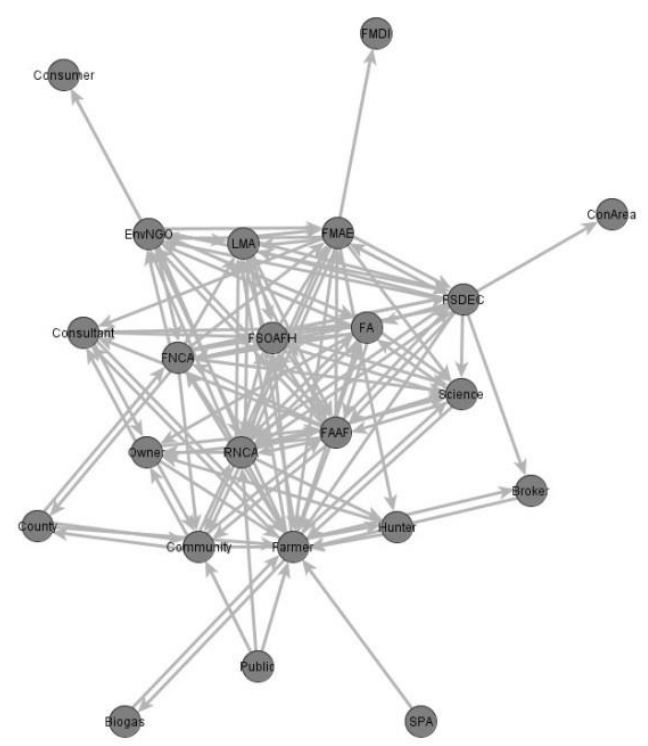


Figure A2.4. Regional network when five and more links between actors were mentioned

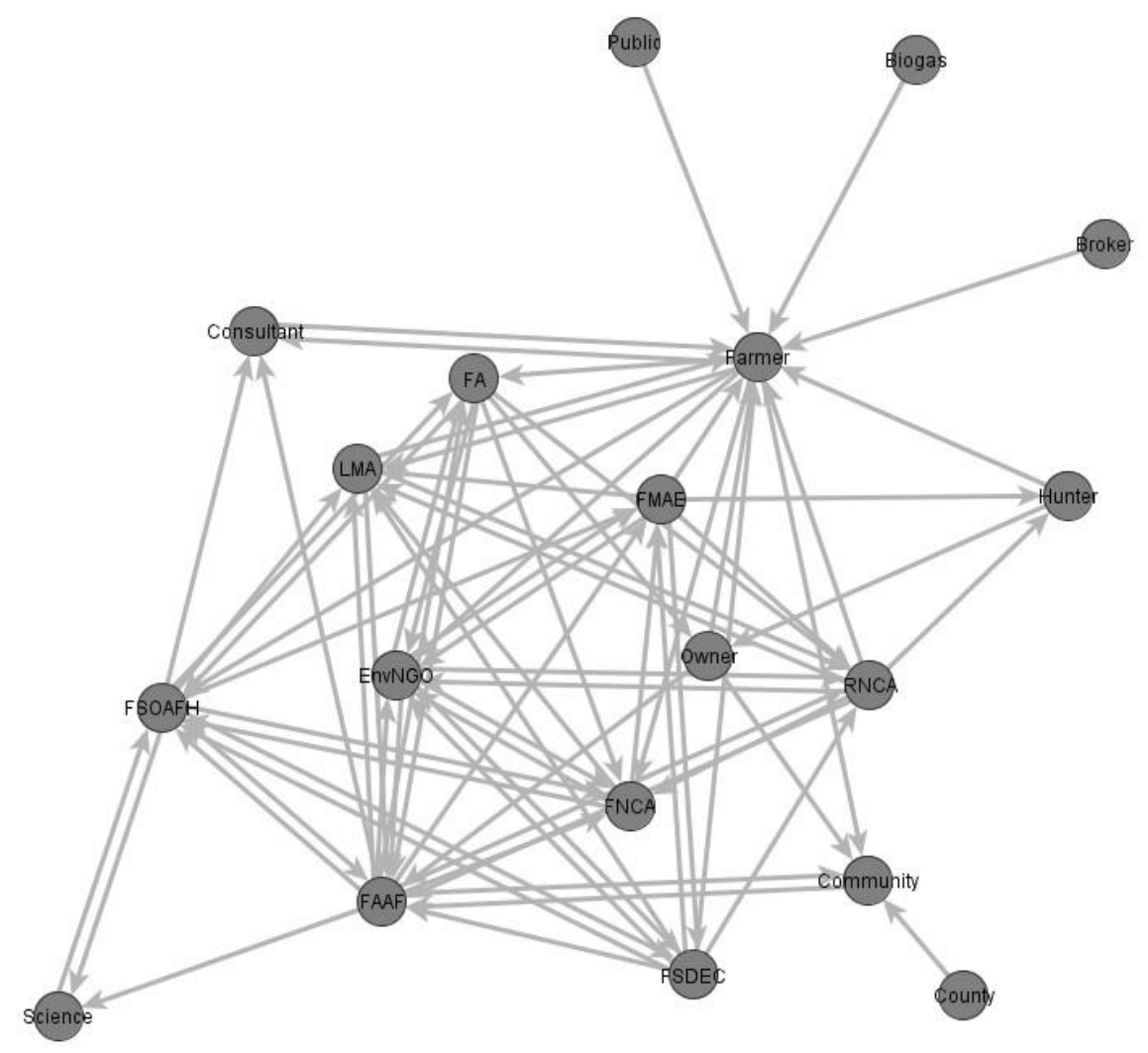




\section{Appendix 3.}

Figure A3.1. Local network when two and more links between actors were mentioned

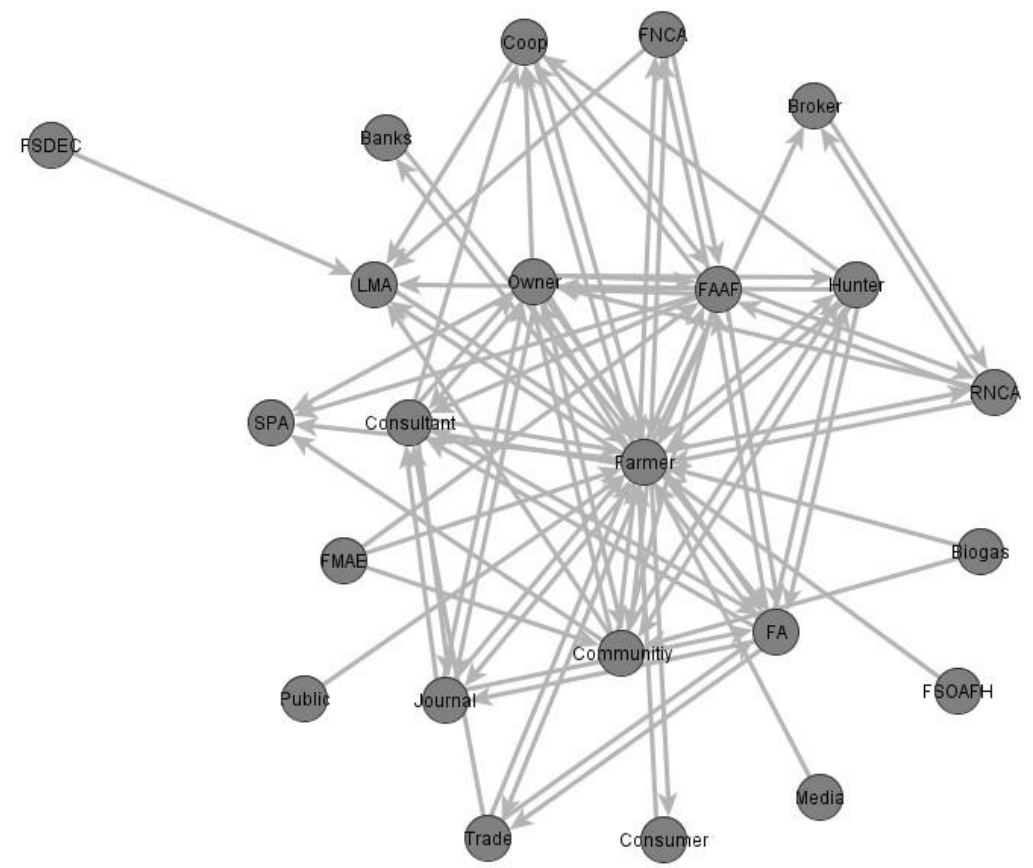


Figure A3.2. Local network when three and more links between actors were mentioned

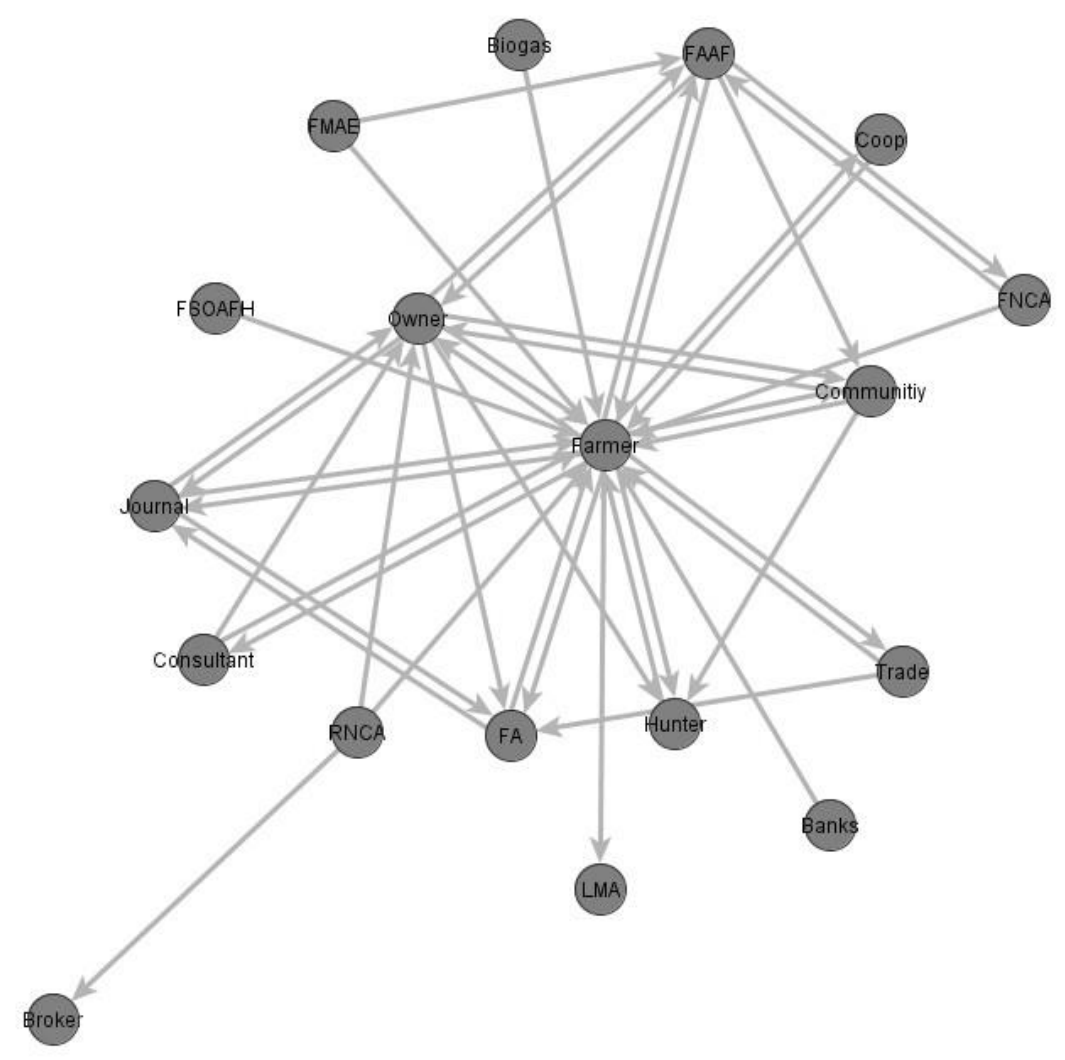


Figure A3.3. Local network when four and more links between actors were mentioned

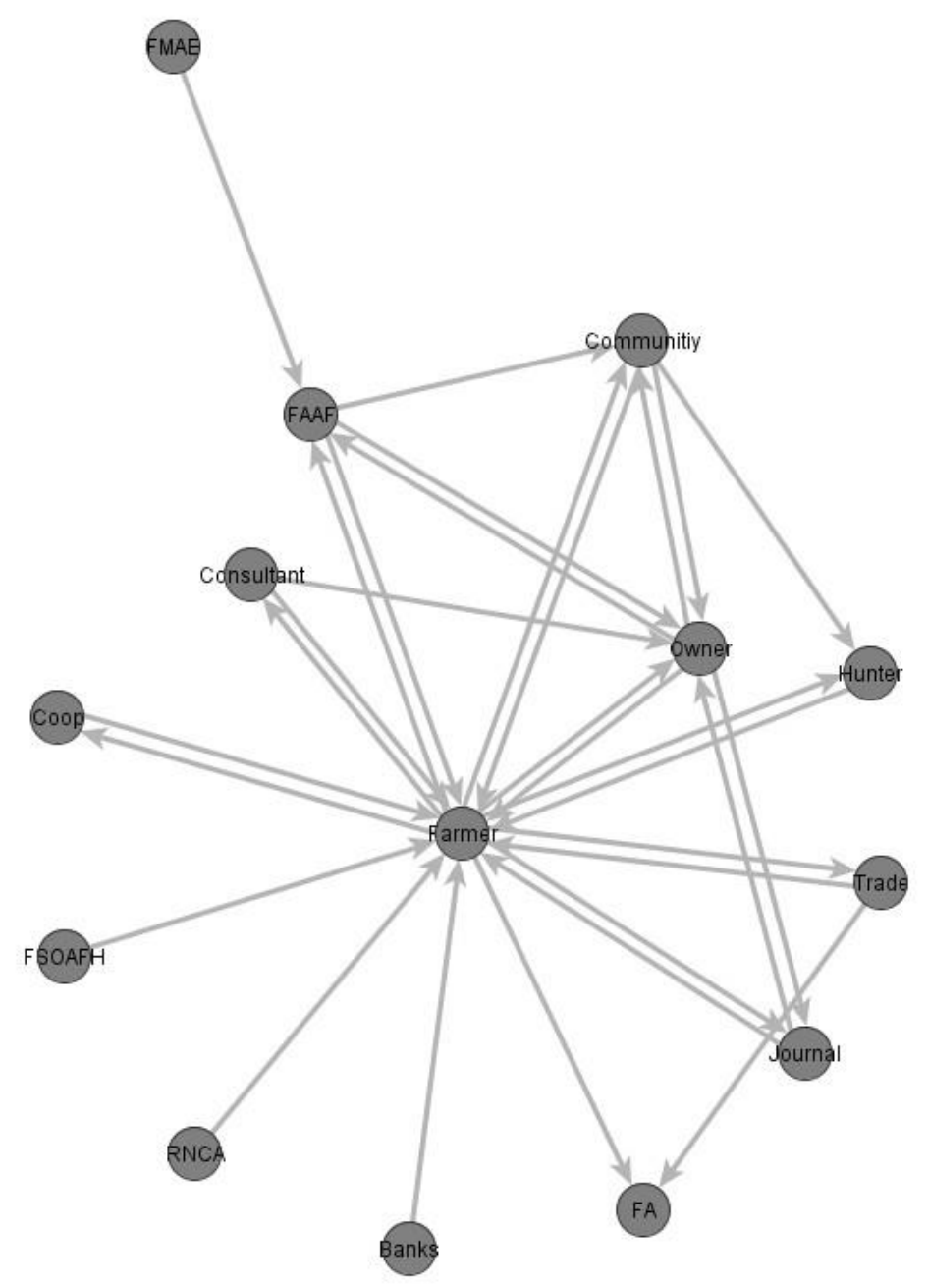

